\title{
Vocational Pedagogy in Perspective Vocational High School Curriculum
}

\author{
Isma Widiaty ${ }^{\mathrm{a}, 1}$, Ana $^{\mathrm{a}}$ \\ ${ }^{\mathrm{a}}$ Technical and Vocational Education Faculty, Indonesia University of Education \\ J1. Dr. Setiabudhi No.207 Bandung, West Java, INDONESIA \\ 1isma@upi.edu
}

\begin{abstract}
The objective of the research is to study vocational pedagogy in perspective vocational High School Curriculum (SMK). The method in this research used a qualitative with indepth interviews, documentation, and focus group discussion to discuss about concept, design, and developing vocational pedagogy in perspective SMK Curriculum. The results showed that vocational pedagogy is the art, principles and method of learning, teaching and instruction used in TVET involves what to teach (content) and how to teach (process). Design vocational pedagogy successful observed from teachers who have a passion, subject knowledge, and capable of inspire students consequently, that the learning process dynamically. Developing vocational pedagogy is a process that must continue to be realized in suitability with the demands of the industry are rapidly changing and dynamic. Implications of the research is vocational pedagogy has a very important meaning and the basis for developing a culture of learning that is effective and efficient.
\end{abstract}

Index Terms- curriculum relevance, vocational high school, vocational pedagogy

\section{Introduction}

Vocational pedagogy in vocational education context especially vocational high school (SMK), is an important issue to conduct reorientation process in teaching and learning in SMK. The learning process is expected to prepare learners with some competencies needed in work world. The challenge faced by SMK students which comes from work world becomes more various seen from quantity, quality, and competitiveness of foreigner workers.

Industry world seems more opened and competitive. "An improvement in vocational skills for employability and citizenship can only be realized if there is an improvement in the quality, effectiveness and relevance of teaching. These key principles can be actualized through the execution of vocational pedagogy" [8].

Developing a relevant curriculum in vocational education is an everlasting need. It is a task which must be done continuously along with the changeable time. A vocational education curriculum developed by referring to the relevance principle is the foundation of many essential policies which will give a right direction for the success of program planning and implementation in vocational education [6].

What is meant by vocational pedagogy in this paper involves what to teach (content) and how to teach (process); both are viewed as important principles of learning process in vocational education which should refer to competencies needed by industry world.

Vocational pedagogy is an important principle parallel to the demand of development direction curriculum which should considers process orientation and learning content as a whole. Thus, a meaningful learning can be acquired. Both orientations are called Pedagogical Content Knowledge (PCK). It should be an important part of teacher professionalism development parallel with the demand of curriculum [10].

\section{Method}

In this study, the researchers used a qualitative method to describe in depth data about vocational pedagogy in perspective vocational High School Curriculum. Data collected consist of the concept, dimension, design, and developing vocational pedagogy in perspective vocational High School Curriculum.

Data collection was conducted from February 2014 until May 2014.

\section{Techniques and Sources Data Collection}

1.1. In-depth interviews

Table 1.

In-depth interviews was conducted with 20 key informants

\begin{tabular}{ll}
\hline Quantity & Position at SMK \\
\hline 4 persons & $\begin{array}{l}\text { Vice Principal for } \\
\text { Curriculum }\end{array}$ \\
4 persons & $\begin{array}{l}\text { Vice Principal for } \\
\text { industrial relations }\end{array}$ \\
4 persons & Head of the Study \\
8 persons & $\begin{array}{l}\text { Program } \\
\text { Subject Teacher } \\
\end{array}$ \\
\hline
\end{tabular}

1.2. Documentation

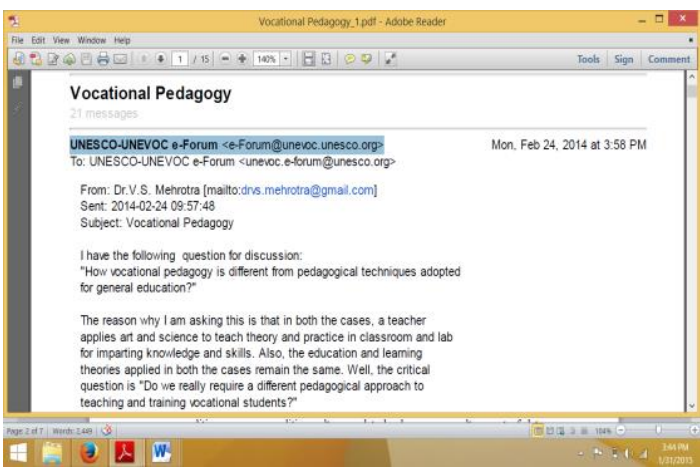

Resources: UNESCO-UNEVOC e-Forum

Documentation collected in this study, derived from an online discussion (e-forums) conducted by experts from 
several countries vocational field who are members of a mailing list of UNESCO - UNEVOC E - Forum.

Special Topics covered in the span of February 2014 March 2014 is about vocational pedagogy. The online discussion is followed by 22 people from various countries.

\subsection{Focus Group Discussion}

Table .3

Focus Group Discussion was conducted with 15 key informants

\begin{tabular}{ll}
\hline \multicolumn{1}{c}{ Quantity } & Areas of Expertise \\
\hline 7 persons & $\begin{array}{l}\text { Vocational Curriculum } \\
\text { Experts } \\
\text { technological and vocational } \\
5 \text { persons }\end{array}$ \\
$\begin{array}{l}\text { education experts } \\
\text { vocational learning experts }\end{array}$ \\
\hline
\end{tabular}

\section{Analysis Data}

Data was analyzed using triangulation techniques derived from in- depth interviews, documentation, and focus group discussions .

These three data sources has become a key ingredient for the analysis of data with the principle of complementarity and strengthen existing data

\section{Results and Discussion}

\section{Concept Vocational Pedagogy in Perspective SMK Curriculum}

Vocational pedagogy is a terminology in vocational education which is meant dynamic, parallel to the fast and dynamic development of science and technology. Vocational pedagogy should be developed continuously based on science and development technology and industry demand which is continuously developed.

Pedagogy is the science, art, and craft of teaching. Pedagogy also fundamentally includes the decisions which are taken in the creation of the broader learning culture in which the teaching takes place, and the values which inform all interactions [9].

Vocational curriculum development should fulfill the need and process of curriculum content implementation. Moreover, the development should be recovered from time to time particularly should be suited to the need of work field. Vocational pedagogy in this context is defined as carrier-oriented education [12]. It is an important meaning of curriculum relevance process in vocational education which includes the meaning of learning process that should always adapt to the development of work field demand (vocational pedagogy in progress).

Vocational pedagogy is also defined as a science, art, and "creation". Fundamentally, vocational pedagogy consists of how to decide an important policy in learning process, so learning situation and learning culture that are able to develop values and maximum interaction from all learning components can be created [9].

Vocational pedagogy has a broader definition in order to optimize vocational education. It is not only about how to teach and what to teach but also related to why to teach. It results in a new thought that teaching is an art and should create learning which is suited to philosophical need of vocational education - to produce human resource suitable to the need of work field and able to give positive contribution to economy development.

Vocational pedagogy in the area of vocational teacher education curriculum is defined as a special teaching method course [8]. The concept of vocational pedagogy involves instructional strategies to conduct learning process in vocational education. Vocational pedagogy relates to learner learning experience either in school or in work world.

The implementation of vocational pedagogy in vocational education intends to be an effort to organize learning environment to develop knowledge, skill, attitude, and learning setting which are able to present a real learning situation as in work field.

Vocational pedagogy need to consider how curriculum goals and content might be conceptualized for vocational education. The scheme is founded in socio-historical activity theory is called sociogeneses [2]. Goals and content vocational curriculum needs to accommodate indigenous social and cultural

vocational pedagogy involves what to teach and how to teach [8]. What to teach associated with learning content. Vocational learning content should be derived from the competencies needed in the world of industry.

Curriculum developers, before designing the curriculum need to first analyze what skills students should possess in connection with a particular task or profession in society . The results of this analysis, as the basis for designing the curriculum content expected more effectively and in accordance with the needs of the community.

This is essentially the meaning of the relevance of the curriculum in which the curriculum developers need to look at the needs that exist in the community so that what is taught in school is relevant to the needs in the community

How to teach associated with teaching strategies implemented by teachers at school. Teachers are expected to provide meaningful learning experiences for students.

Meaningful learning experiences for students influenced by the learning material presented by the teacher. Learning materials that match the needs of learners will open up opportunities learners experiencing learning process meaningful.

This meaningful learning experience, will encourage students to be more serious about learning . Learning environment will be more lively, attractive, and the needs of learners. Learning materials provided to students also must be able to ensure that learners have sufficient stock to plunge in the community or the industry optimally .

Curriculum development in vocational education, should have focused on students (student centered) and equip students with problem solving in the field (problem based learning).

\section{Curriculum Design in Vocational Pedagogy Perspective}

The purpose of vocational education is to produce human resource suited to the need of stakeholders especially industry. Therefore, the process of curriculum development in vocational education ideally should actively involve 
industry practitioners in the stage of planning, implementation, and evaluation.

Learners as the main focus of the curriculum was originally derived from the public and will someday return to the community. The philosophy that has led to the belief that learners should fully understand the problems and needs of the community. Through knowledge and new concepts are acquired, it is expected that learners can identify community needs and even able to solve the problems that occur in the community. The curriculum in this context would have " meaning " significant to the development of society into a better direction .

In other words, academic collaboration between school and work world is very urgent in order to produce graduates with good quality to become qualified workers. The learning by collaborative with industry can improve a learning process which emphasizes on student and can enhance learning quality [4].

Many ways and strategies was conducted to "approach" vocational education curriculum to industry need, one of them was through In House Training (IHT) activities which involved industry in curriculum development process. Nevertheless, all this time the process, if it is related to curriculum relevance, too focuses on the stage of curriculum planning. It would be better if the relevance process was also conducted in the stage of learning process in a school that is considered as the heart of learner competencies development in vocational education.

The collaboration principle of school and industry is conducted through engagement of industry practitioners into the activities. In planning step, school and industry together designed the learning process which is able to produce graduates with relevant competencies to industry need.

The collaboration is also occurred in the implementation facet in which industry practitioners together with teachers take a role as observer who investigated learning process, learning setting, learner behavior, teacher-student interaction, student-student interaction, and utilized practice tools. The real situation and condition of learning process can be observed directly both by teacher community and by observers from industry.

In the final stage teacher together with industry practitioners can conduct reflection of learning collaboratively. Thus, a lesson or insight of the learning can be obtained in order to fix the future learning process suited to the need of work world. The condition is called as collaboration between education specialists and general education teachers [7].

\section{Developing Vocational Pedagogy in the perspective of the relevant vocational curriculum}

One of important curriculum development principles is relevance principle. Curriculum relevance is urgent to be examined since the fast development of science and technology affects to the speedy alteration in society.

The change of social condition, economy, politics, culture, and technology may result on out of date curriculum if the curriculum does not adapt to the development. The process of curriculum development in vocational education should consider three essential factors “... changes in occupations, technology, and community" [13].
The development of vocational pedagogy at least in the following two important aspects. First, vocational pedagogy applies the learning principle of student-centered. Student knowledge and skill are two essential components of pedagogy in vocational education that have to be built. Student-oriented learning should pay attention to learning style of each learner.

This learning is also characterized by the process which develops student creativity and critical thinking within flexible learning condition that possibly makes student continuously developed based on his potentials.

Second, vocational pedagogy is a learning principle which should always connect learner competencies to the need of work world. Learner competencies are built through learning process with problem based learning approach in which learner is directed and faced to various solutions of industry's real problems. The approach beckons the existence of pedagogic collaboration between school and industry.

The change in jobs becomes the factor influencing development of vocational education curriculum. The needs of work world toward competent workers and dynamic developed job sectors are the challenge for vocational education curriculum.

The more sophisticated development of technology surely requires suitable qualification of workers to the existing technology development. Vocational education curriculum always should be able to produce workers suited to the technology development. One of vocational education tasks is to serve society to achieve better life. Curriculum should be arranged based on society development and the purpose in supporting a better society.

Relevance will connect the existing potential of work field to graduate competencies in fulfilling the job requirements. The graduates of vocational education who do not fulfill the requirements and the needs of work field indicate vocational education "failure" [3], [5]. Relevance of curriculum will be significantly influenced by projection change, existing job requirements, and work field demand. Dynamics of work field is the challenge for curriculum developers in vocational education.

Relevance of curriculum, in implementation context, will be seen from learning process in classroom. Vocational teachers should be able to develop student competencies which are suitable to the needs of work field. Based on this context, the implementation of curriculum in classroom will find the meaning of relevance.

The quality of vocational graduates directly or indirectly have an effect on the economy of a country. The quality of vocational education graduates are unemployable would cause an unfavorable effect on the economy of a country that would cause symptoms of economically inactive [13].

Vocational education as a kind of education that is in charge of producing qualified labor to fill certain types of work in the industry have a significant impact on the social and political aspects of a country. " Vocational education plays a key role in economy, social, and political development of every nation " [1].

Curricula that are not relevant to the needs of the workforce and the community will lead to vocational education can not be defended well . Vocational education will be able to survive if the curriculum can serve as a 
means to connect between the needs of the workforce with the quality of graduates produced to fill these jobs. L

Likewise, vocational graduates will be able to survive (the learner survival) in the world of work if this curriculum relevance function can run well. This type of work changed, the curriculum should also be changed, as well as workers[11] .

\section{Conclusion}

Vocational pedagogy has a broader definition in order to optimize vocational education. It is not only about how to teach and what to teach but also related to why to teach. It results in a new thought that teaching is an art and should create learning which is suited to philosophical need of vocational education - to produce human resource suitable to the need of work field and able to give positive contribution to economy development.

Curriculum design in vocational pedagogy perspective includes two important principles; First; vocational pedagogy applies the learning principle of student-centered. Second; vocational pedagogy is a learning principle which should always connect learner competencies to the need of work world.

The principle development of vocational pedagogy which becomes a unique characteristic of learning process in vocational education. Developing vocational education curriculum which is relevant to industry need is a process that should be conducted continuously

\section{Referenses}

[1] Amankwah, E dan Swanzy, P (2011). "The Role of Stakeholders in Building Adequate Competences in Students for the Job Market". International Journal of Vocational and Technical Education. 3, (8), 107-112.

[2] Billet, S. (2010). "Vocational Curriculum and Pedagogy: an activity theory perspective". European Educational Research Journal, Volume 2, Number 1, 2003

[3] Canavan, B \& Doherty, R. (2005). Technical Curriculum in ScotlandFit for Purpose?PATT-15 April 18-22, 2005 Technology Education and research: Twenty Years Retrospect.

[4] Cheng-Ting, C. Diane W. K. \& Ellen McIntyre. (2008). Helping Teachers Work Effectively with English Language Learners and Their Families with Lesson Study. The School Community Journal, 18(1).

[5] Hodge, K. A. \& Lear, J. L. (2011). Employment Skills for 21st Century WorkPlace: The Gap Between Faculty and Student Perception. Journal of Career and Technical Education. 26(2), 28-41.

[6] Komla M. E. \& Ansah C. O. (2011). Linking Tertiary Institutions to industries: Evidence from the Vocational and Technical Education Departement of University of Cape Coast. International Journal of Vocational and Technical Education, 2(5), 53-60.

[7] Lanore D. B. (2008). Lesson Study: Implications of Collaboration between Education Specialists and General Education Teachers. Thesis. The Faculty of Humboldt State University.

[8] Lubis, S. (2010). Concept and Implementation of Vocational Pedagogy in TVET Teacher Education. Proceedings of the $1^{\text {st }}$ UP International Conference Technical and Vocational Education and Training, Indonesia 10-11 November 2010.

[9] Lucas, B. Spencer, E. \& Claxton, G. (2012). How to Teach Vocational Education. A Theory of Vocational Pedagogy. Center for Skil Developtment University of Winchester. December 2012.

[10] Matsubara, K. (2013). Lesson Study and Curriculum Developtment from Japanese Experience. The $6^{\text {th }}$ Lesson Study Conference. FPMIPA UPI, August 24, 2013.

[11] Matthew, AO and Ede, EO. (2010). "Integration of New Technological Innovation in Automobiles into the Curriculum for Nigerian Technical College Programmes".International Journal of Vocational and Technical Education. 2. (5), 89-94
[12] Mohaffyza, M. M. et al. (2012). Vocational Pedagogy a Dimension of Vocational Learning with Workplace Requirement. Journal of Technical Education Training, 4(1).p.23-30

[13] Oloruntegbe, K. O. et. al. (2010). Reconceptualization of African Vocational and Technological Education for Emergent Globalization, relevance and Sustainable Economic Development. International Journal of Vocational and Technical Education, 2(4), 55-61.

[14]UNESCO-UNEVOC e-Forum e-Forum@unevoc.unesco.org 